\title{
Cross-border migrants in Russia: language of the description dynamics
}

\author{
DOI: $10.31551 / 2410-2725-2018-4-3-466-478$
}

\section{Dyatlov Victor Inokentyevich}

Doctor of History, professor of the Department of World History and International Relations of Irkutsk State University. The Russian Federation, 664025 Irkutsk Chkalov str. 2. E-mail: vikdyatlov@yandex.ru

\begin{abstract}
At the turns of 19-20th and 20-21st centuries Russia faced extremely complex problem of mass cross-border labor migrations that demanded development of adequate language of the description of the happening processes. It is important not only because there is a communication of language of the description and heuristic potential of the researches which are conducted in it: language of the description influences the nature of relationship in society, is their powerful regulator, in many respects form them. Therefore it is so important to look what and from the words are undertaken what reasons are behind their choice. It is important to understand how language of the description reflected public moods, to reveal possible dynamics of process, to raise a question of its continuity or discretization.

Today the Russian society changes. Also its relation to a problem of presence of migrants changes. Process of judgment and verbalization of a migration phenomenon in Russia is not complete. Keywords: migrations; description of language; cross-border migrants; verbalization; migration policy.
\end{abstract}

\section{Ресейдегі трансшекаралық мигранттар: сипаттау тілінің динамикасы}

\section{Дятлов Виктор Иннокентьевич}

Тарих ғылымдарының докторы, Иркутск мемлекеттік университетінің дүниежүзілік тарих және халықаралық қатынастар кафредрасының профессоры. Ресей Федерациясы, 664025, Иркутск қ, Чкалов к, 2. E-mail: vikdyatlov@yandex.ru

Аңдатпа. XIX-XX және XX-XXI ғасырлар шекарасында ресейлік жаппай трансшекаралық еңбек көшіқонының өте күрделі мәселесі болды, ол процестерді сипаттау үшін тиісті тілдің дамуын талап етті. Бұл түсініктеме тілі мен зерттеудің эвристикалық әлеуеті арасындағы байланыстың болуымен қатар ғана емес, сонымен қатар: сипаттама тілі қоғамдағы қарым-қатынастың сипатына әсер етеді, олардың күшті реттеушісі болады және оларды көптеген жолдармен қалыптастырады. Сондықтан, қандай сөздердің қайдан шыққанын және олардың тандауларының негізінде қандай себептер жасырылғандығы маңызды. Сипаттау тілі қоғамдық пікірді қалай көрсететінін, процестің ықтимал динамикасын анықтауға, оның сабақтастығы немесе үзіліссіздігі туралы мәселені көтеру жолдарын түсіну үшін маңызды. Бүгін Ресей қоғамы өзгеруде. Оның мигранттардың мәселесіне деген көзқарасы да өзгеруде. Ресейдегі көші-қон құбылысын түсіну және вербализациялау процесіаяқталмады.

Түйін сөздер: көші-қон; сипаттау тілі; трансшекаралық мигранттар; вербализация; көші-қон саясаты.

\section{Трансграничные мигранты в России: динамика языка описания}

\section{Дятлов Виктор Иннокентьевич}

д.и.н., профессор кафедры мировой истории и международных отношений Иркутского государственного университета. Российская Федерация, 664025, г. Иркутск, ул. Чкалова, 2. E-mail: vikdyatlov@yandex.ru

Абстракт. На рубежах XIX-XX и XX-XXI веков Россия сталкивалась с чрезвычайно сложной проблемой массовых трансграничных трудовых миграций, что требовало выработки адекватного языка описания происходящих процессов. Это важно не только потому, что существует связь языка описания и эвристического потенциала осуществляющихся на нем исследований: язык описания воздействует на характер взаимоотношений в обществе, является их мощным регулятором, во многом формируют их. Поэтому так важно посмотреть, какие и откуда берутся слова, какие причины скрываются за их выбором. Важно понять то, как язык описания отражал общественные настроения, выявить возможную динамику процесса, поставить вопрос о его непрерывности или дискретности.

Сегодня российское общество меняется. Меняется и его отношение к проблеме присутствия мигрантов. Процесс осмысления и вербализации миграционного феномена в России не завершен.

Ключевые слова: миграции; язык описания; трансграничные мигранты; вербализация; миграционная политика. 


\section{ӘОЖ/ УДК 167:133.556.4(470)}

\section{Трансграничные мигранты в России: динамика языка описания ${ }^{1}$}

\section{В.И. Дятлов}

На рубежах XIX-XX и XX-XXI веков Россия сталкивалась с чрезвычайно сложной проблемой массовых трансграничных трудовых миграций. Для России ситуация осложнялась не только масштабами миграционных потоков, огромной ролью мигрантов в экономике всей страны или отдельных ее ключевых регионов, остротой общественной реакции, геополитическими страхами, но и каждый раз новизной, неподготовленностью общества и властей к ее адекватному осмыслению и регулированию.

Нельзя сказать, что у России не было к концу XIX века опыта регулирования трансграничных миграций. Привлечение на государственную службу иностранцев, переселение из-за рубежа целых религиозных или национальных групп в качестве аграрных колонистов на вновь осваиваемые земли, наделение их особыми правами, привилегиями и обязательствами - все это заставляло фрормировать соответствующие правовые нормы, государственные механизмы и системы практик.

Тем не менее, обе волны трансграничных трудовых мигрантов стали абсолютно новой проблемой для российского общества и властей, вследствие этого - огромным шоком. И дело не только в масштабах и залповом характере миграционных потоков, в новизне их трансграничного характера, в огромном воздействии на принимающее общество и в болезненном характере реакции этого общества на проблему. В этом, конечно, тоже. Но главное состоит в уникальном для российского опыта спонтанном, независимом от державной воли характере этих миграций. Впервые огромное количество людей пересекало и пересекает российскую границу по собственному выбору и решению, вне рамок государственно организованных, регулируемых и спонсируемых программ.

Все это заставляет осмысливать природу нового явления, для этого необходимо назвать его, найти подходящие слова и определения. Найденные слова в свою очередь воздействуют на характер взаимоотношений, являются их мощным регулятором, во многом фрормируют их. Поэтому так важно посмотреть, какие и откуда берутся слова, какие причины скрываются за их выбором. Обычно этот выбор обусловлен традицией, интересами, контекстом. Нам важно понять то, как язык описания отражал общественные настроения, выявить возможную динамику процесса, поставить вопрос о его непрерывности или дискретности.

Принципиально важен здесь исторический контекст. Обе залповые волны трансграничных трудовых мигрантов пришлись на переходные, переломные эпохи в жизни страны. Позднеимперская и постсоветская ситуации формируют не только новые уклады жизни, но и новые слова, образы, метафоры, новые понимания и дискурсы. И ситуация «двух пришествий» мигрантов, разделенных целой эпохой «железного занавеса», когда они полностью выпадали из обыденной жизни и из исторической памяти, открывает большие возможности для сравнения и анализа.

\footnotetext{
${ }^{1}$ Исследование выполнено в рамках базовой части государственного задания Минобрнауки России (проект «Дискурсивные механизмы конструирования границ в гетерогенном обществе востока России», задание №28.9753.2017/БЧ) и гранта РФФИ (проект № 16-03-00100 «“Этнические рынки” в пространстве постсоветского сибирского города»)".
} 
«Наплыв желтой расы»: трансграничные мигранты на дореволюционном Дальнем Востоке. Присоединение Дальнего Востока к России во второй половине XIX века, освоение этого огромного и невероятно удаленного от метрополии края («далекой окраины» по распространенному определению тех лет), потребовало создания там первичной административной, военной, коммуникационной, экономической инфраструктуры, ее обслуживания, поддержания элементарной жизнедеятельности формирующегося населения. Это создало огромный платежеспособный спрос на рабочую силу, удовлетворить который за счет российских источников было просто невозможно. Он и создал мощный и постоянно растущий приток трудовых мигрантов из соседних стран Китая, в меньшей степени - из Кореи и Японии. Их роль в стратегически важном регионе была столь велика, что это воспринималось как общеимперская проблема, требующая проведения специальной политики.

Преобладающий по численности поток из Китая составляли временные, в значительной части сезонные, мигранты. Китайские мигранты преобладали в торговле и личных услугах, ремеслах, коммунальном хозяйстве, строительстве, золотодобывающей промышленности, заметную роль играли в сельском хозяйстве в качестве арендаторов и наемных рабочих. Точных оценок их численности нет в силу постоянных изменений, сезонности, слабой постановки учета и контроля. Но в некоторые годы она превышала сотню тысяч человек (по оценке А.Г. Ларина 200-250 тыс. в 1910 г.), т.е. составляла 10-12\% населения региона (Ларин 2009: 20-21).

К 1912 году численность мигрантов из Кореи оценивалась в 65 тыс. человек, в т.ч. 17 тыс. имевших российское подданство (Петров 2001: 46). По фрорме - трудовые мигранты, по сути - почти беженцы от невыносимых условий жизни. Они перебирались в Россию семьями и с твердым намерением остаться там навсегда. Это создавало огромный стимул к адаптации - корейцы добивались получения российского подданства, для этого массово принимали православие, стремились дать детям российское образование и знание языка. Составляя самый низкооплачиваемый и бесправный слой рабочих на золотых приисках и в городской экономике, они заняли заметное место в сельском хозяйстве. Российские власти быстро и высоко оценили их лояльность, умение вести сельское хозяйство в местных условиях, огромное трудолюбие. С проблемами и трудностями, но многим из них удалось добиться российского подданства, права на получение земли и возможности создавать свои деревни. Довольно быстро сфрормировалась немногочисленная, но энергичная русифицированная и получившая современное образование элита.

Японских мигрантов было мало, около пяти тысяч человек в 1902 г., но они нашли свою нишу в экономике, занявшись профессиями, требующими современного образования и ремесленной квалификации.

Это был, видимо, первый в истории России случай массовых трансграничных трудовых миграций, не организованных властями империи. На этой рабочей силе держалось сельское хозяйство, золотопромышленность, строительство, сорера обслуживания и личных услуг, торговля и общественное питание.

Эта ситуация потребовала осмысления и вербализации. Основным производителем смыслов и слов были военные и гражданские чиновники метрополии и колонии, а также публицисты, путешественники, ученые. Нередко эти люди отличались большим колониальным опытом, высокой гуманитарной культурой, отличными аналитическими способностями, хорошим знанием региональной ситуации. 
Решая задачу натурализации мигрантов, они оценивали ситуацию в категориях подданства и гражданства. Нельзя сказать, что малочисленный и только фрормирующийся государственный аппарат «далекой окраины» справлялся с этим чрезвычайно трудным делом отлично, но механизм выдачи виз, документов, регистрации, сбора пошлин и т.д. функционировал. Все это формировало набор рутинных бюрократических практик, процедур, развитое делопроизводство и соответствующую терминологию.

Привычным был сословный подход. Не случайно обязательным условием предоставления российского подданства было принятие православия. Будущий генерал-губернатор П.Ф. Унтербергер констатировал, что принятые в русское подданство «корейцы-землепашщы были приравнены к крестьянским обществам и на них было распространено крестьянское общественное самоуправление» (Унтербергер 1990: 116). В каком-то смысле, в качестве группы сословного порядка можно рассматривать т.н. «зазейских маньчжур». Это было оседлое, крестьянское население (около 7000 китайцев, маньчжур и дауров в 1900 году) Зазейского района, примыкавшего к Благовещенску. По Айгуньскому договору, район отошел к России, но его жители остались под юрисдикцией китайских властей. В этом же контексте можно рассматривать массовое и повсеместное использование термина «манзы». Это не совсем этноним (т.к. манзами называли и ханьцев, и маньчжур), но и не характеристика подданства. Так называли вначале всех оседлых и «бродячих» китайцев, проживавших в крае на момент его присоединения к России, а затем и всех выходцев из Китая, включая и сезонных мигрантов. Но это не относилось к жителям собственно Китая.

Термины китайцы, корейцы, японцы использовались широко, в т.ч. и в качестве этнонимов. Это особенно заметно на примере корейцев, многие из которых уже родились в России, имели российское подданство, приняли православие, были приписаны к крестьянскому сословию. В глазах местного населения и властей они привычно рассматривались и в качестве корейцев, вместе с жителями Кореи.

Однако традиционные категории подданства и сословия, быстро входящие в оборот этнический дискурс и терминология, явно не удовлетворяли общество и власти эпохи поздней Империи. Этнические категории представлялись зачастую слишком частными и не совсем операциональными. С другой стороны, власти не видели в трансграничных мигрантах из соседних дальневосточных государств обычных иностранцев, не требующих специального, отдельного отношения, регулирования и вербальной оценки, а значит и законодательства, и политики. По категорической оценке П.Ф. Унтербергера, «наши законоположения о правах иностранцев, живущих на русской территории, к китайцам во многом совершенно неприемлемы» (Унтербергер 1990: 274).

Не получили широкого распространения и термины «миграционного поля». Само слово мигрант почти не употреблялось, явный дефицит социальноэкономического понимания проблемы лишь в небольшой мере компенсировался широким использованием категории «желтый труд». В публикациях специалистов содержится его квалифицированный анализ: отраслевая и региональная динамика применения китайской и корейской рабочей силы, уровень ее оплаты, структура расходов, масштабы вывоза рублевой массы из страны (Л.Г. 1916; Граве 1912; Мацокин 1911; Панов 1910; Предварительные итоги 1925)².

\footnotetext{
${ }^{2}$ Междуведомственное совещание по делам Дальнего Востока. Справка по вопросу о мерах борьбы с китайской торговлей в Приамурье. (Б.м.), (б.г.);
} 
При этом слово «желтый» играло не меньшую, а возможно и большую роль, чем слово «труд».

Ответ на сформировавшийся запрос дал общемировой комплекс представлений о мире, идеологем, стереотипов, страхов и предрассудков, известный как «желтая опасность» («yellow peril»). В его основе лежал расовый подход, исходивший из презумпции природной, органической принадлежности человека к «расе», в которой биологические характеристики предопределяют качества интеллектуальные, моральные и духовные. Его образ жизни, поведение, систему ценностей и групповую лояльность. Принадлежность к «расе» как к природному телу не является вопросом личностного выбора, ибо нельзя выбрать цвет кожи или разрез глаз.

Использование такого подхода давало возможность перевести оценку, принципы правового регулирования и конкретные управленческие практики из категорий подданства, этничности, социально-экономического статуса («мигранты») в категорию расы. А значит получить основание для особого, специального отношения и особой политики.

Вербально этот комплекс представлений реализовался в одном из самых распространенных словосочетаний той ситуации, страны и эпохи - «наплыв желтой расы». Эти слова стали ключевой рабочей метафорой, широко, привычно и повсеместно употреблявшейся в обыденной речи, публицистике, прессе, бюрократическом обороте и делопроизводстве, офрициальных документах различного уровня - вплоть до текстов законопроектов.

Слово «наплыв» в чем-то можно соотнести с миграционным дискурсом. «Наплыв» - это движение. В нем сконцентрированы значения стихийности, почти природности (аналогично наводнению, например), катастрофичности. Здесь нет обратного движения, поэтому формируется представление о постоянном стихийном нерегулируемом притоке, грозящем вселенским потопом. Отсюда абсолютно отрицательная коннотация: «наплыв» - это потоп, бедствие, с которым необходимо бороться. А так, как это катаклизм, то здесь нет мигранта, человека, принимающего решения, нет субъекта действия вообще.

«Наплыв», как почти природное, тектонической движение, органически увязывается с категорией «желтой расы», с расовым подходом. Наиболее ярким проявлением расового подхода было общепринятое и общераспространенное употребление эпитета «желтый». Его широко и свободно, в качестве нормального и привычного, употребляли в обыденной речи представители и простонародья, и элитных слоев. Им оперируют журналисты, исследователи, ведомственные аналитики, чиновники, высшие администраторы. При этом, в слово «желтые» могли закладываться разные смыслы и значения - от подчеркивания расовых коннотаций («желтая раса») до удобного агрегирования совокупности китайцев, корейцев и японцев. Слово «желтый» могло нести в себе оценочность (чаще всего отрицательную), но могло быть и нейтральным. Но в любом случае - это манифестация абсолютной и природной чужеродности. В эпитете «желтый» сконцентрирована природа, суть отношений и страхов. Это господствующий дискурс - а не просто часть случайно сложившегося термина и понятия.

Эпитет «желтый» употребляется наряду с этнонимами. Грамотная публика, да и значительная часть неграмотного населения, особенно на Дальнем Востоке, знала, что есть китайцы, японцы, корейцы, монголы и т.д. Многие хорошо представляли, в чем состоят различия между ними. Чиновники, военные, профессиональные эксперты, анализируя конкретные явления и процессы в регионе, привычно мыслят в этих категориях. 
Если давать общую оценку, то конкретные проблемы развития региона, вопросы его управления - в той части, что связаны с мигрантами - обычно рассматривались в категориях сословия, этничности или подданства. Но как только анализ выходил в плоскость выстраивания геополитики, стратегии, общего взгляда на роль региона в стране и в мире - начинает господствовать «желтый» дискурс.

Различное понимание природы трансграничных мигрантов формировало иногда серьезные политические и административные проблемы. Проект первого в истории России миграционного закона, предложенного дальневосточной администрацией П.Ф. Унтербергера и Министерством внутренних дел, исходил из необходимости ограничить приток и использование труда «желтых» мигрантов. Была предпринята попытка выстроить их особый от других иностранцев правовой статус. Это встретило решительное противодействие в частности МИДа, для которого это были подданные Китая, чей статус не мог быть отличным от статуса других иностранных подданных и граждан (Сорокина 2009; Дятлов 2000).

Идея «желтой опасности» разделялась в России далеко не всеми, но это не сопровождалось протестом против употребления самого эпитета «желтый» или его игнорированием в собственных текстах. Таким образом, наблюдается преобладание расовой терминологии, при одновременном использовании категорий подданства, сословия и этничности. Конфрликта при этом не наблюдается, все они могут использоваться в текстах одного автора в зависимости от контекста и ситуации.

«Лицо географической национальности»: слова советской эпохи. Ситуация с трансграничными мигрантами в первые годы Советской власти была во многом продолжением дореволюционной - на Дальнем Востоке наблюдалось сочетание массовой миграции с попытками установления государственного контроля. Это дополнялось политикой выдавливания мигрантов из сферы торгового предпринимательства. В советских текстах 1920-х годов иногда встречается и категория «желтый». «Великий перелом», начавшийся в 1929 г., стал водоразделом и здесь. Маятниковая трудовая миграция была пресечена, оставшиеся в стране китайцы были частично выдавлены, частично высланы или уничтожены. О них надолго и прочно забыли. Корейцы и китайцы (как группы) были выдавлены или депортированы с Дальнего Востока из опасения того, что могут стать «пятой колонной» для Японии. При этом были очевидны недружественные, а то и просто враждебные отношения их между собой. И единственное, что давало основание верить в такую коллаборацию - их «желтизна».

Затем на долгие годы страна закрылась, проблема трансграничных мигрантов исчезла из общественной практики и массового сознания. Трансграничные миграции иногда практиковались и в условиях «железного занавеса» но в виде организованных властями трансфертов населения при установлении и изменении границ после Гражданской и Второй мировой войн.

И когда начался новый, массовый, спрессованный по времени приток трансграничных мигрантов, вновь обнаружилась слабая готовность к тому, чтобы осмыслить, а для этого назвать френомен. Процесс шел стихийно, методом проб и ошибок. Как это обычно бывает, новые слова и образы первоначально приходили из стереотипов прежних времен и прежних реалий.

Что могла предложить в этом смысле советская эпоха?

Никуда не исчезла, естественно, категория гражданства. Однако ситуация закрытости сформировала в советском обществе дополнительные комплексы «заграницы» и «иностранца», перенасыщенные смыслами и конно- 
тациями, далеко выходившими за пределы правовых взаимоотношений человека и государства ${ }^{3}$.

Косвенно, но связан с «заграницей» комплекс «торгаша» - носителя чуждых ценностей и образа жизни. В его формировании и функционировании сомкнулись и дали мощный эффект официальная пропаганда и массовые традиционалистские антирыночные настроения. Отчасти распространялось это отношение и на «шабашников» - сезонных рабочих-отходников 1960-80-х годов. Это было массовое и устойчивое миграционное явление тех лет, фактически формировавшее рынок труда при его легальном запрете и идеологическом осуждении (Валетов 2008; Siegelbaum, Moch 2014). А заметная роль выходцев из трудоизбыточных южных республик страны, отмеченная и маркированная населением через обобщающее название «армяне», придавал этому феномену национальную, иногда и расовую окраску.

Прямо или косвенно все эти образы, представления и слова соотносились или непосредственно вытекали из ключевого для господствовавшей идеологии дискурса «национального вопроса», «национальных отношений» и «национальной политики». Он воплощался в государственной политике, в практиках обыденной жизни. Через призму «национальных отношений» рассматривалась и расценивалась гигантская совокупность социальных связей и отношений. «Национальная политика» была органической и важнейшей частью государственной политики и государственного строительства, а взгляд на мир, на общественные отношения и связи через призму «национального» (то есть примордиально-этнического) - естественной и практически монопольной позицией подавляющего большинства советских людей.

Прямая привязка «национальности» к происхождению, «крови» подталкивала и к расовым коннотациям. Отсюда массовое использование в обыденной речи откровенно расистски-оскорбительных «черные», «чернозадые», «хачики», «баклажаны» и т.д. (Merlin, Radvani 2003) Однако это официально осуждалось властями. Институт предварительной цензуры позволял им удерживать этот дискурс за пределами публичного пространства.

В концентрированном виде практически все эти дискурсы слились в поздние советские годы в образе «кавказца» - временного мигранта из советской, но культурно чужой провинции. Властно-бюрократический дискурс «отлился» в одиозную формулу «лицо кавказской национальности». Словосочетание, изобретенное чиновниками (Левинсон 2005), пытавшихся осмыслить и формализовать в национальных категориях сложнейшую систему социальных отношений и связей, неожиданно для них оказалось перенасыщенным смыслами. Причем смыслами пейоративными. Этому способствовало и наложение значений «лицо - персона» - «лицо - физиономия», и очевидная абсурдность выделения «географической национальности». Все это переводило словосочетание в явно расовое и расистское поле. Широко, но с оттенком его сомнения в политкорректности, употребляется слово «кавказец» (в кавычках и без). Теоретически, оно находится в одном смысловом ряду с «европейцем», например, включая не только географические, но и социокультурные и иногда даже расовые коннотации. Однако слово «европеец» протеста не вызывает и употребляется широко и свободно. С «кавказцем» сложнее...

\footnotetext{
${ }^{3}$ Об «уникальном советском понятии заграница» см. : Юрчак 2016

4 Лиля Пальвелева. Ключевое слово: «лицо кавказской национальности» // Радио Свобода. 16.05.08 [Электронный ресурс] Режим доступа: (http://234.adru.net//cgi-bin/href/146?444991\&login=radioin\&referer=http\%3A\%2F\%2Fwww.svobodanews.ru), свободный.
} 
Постсоветская ситуация: «Есть такая национальность - гастарбайтеры». Новый массовый приток трудовых трансграничных мигрантов начинается в конце 1980 - начале 1990-х годов. За короткое время они сумели стать и чрезвычайно важным элементом экономической и социальной структуры, и раздражающей, остро дискуссионной проблемой для общества, властей и исследовательского сообщества. Речь идет уже о миллионах людей, выходцев, по преимуществу, из стран Центральной Азии и Китая. Они могут радикально отличаться друг от друга в культурном смысле, но занимать одну социальную нишу. Большинство из них мигранты временные, но постепенно формируется прослойка людей, ориентированных на длительное или постоянное оседание.

Миграционная тема активно осваивается властями и населения. Несмотря на сравнительно малый возраст феномена, российское общество прошло уже несколько стадий в его осмыслении и вербализации. Эти стадии, которые были одновременно и моделями, стратегиями осмысления, можно очень условно описать через образы «кавказца», «китайского мигранта», «таджика» и «гастарбайтера».

Непосредственно от советской эпохи был унаследован образ «кавказца». Он был актуализирован и усилен «залповым» выбросом с Кавказа (как российского, так и обретающего независимость) сотен тысяч новых мигрантов. Массовые и повседневные контакты с новыми мигрантами, по большей части - носителями традиционалистской деревенской культуры, создавали ситуацию острого контраста и конфликта типов и манер поведения. Различия деревенской и городской культур оценивались в привычных «национальных», то есть примордиально-этнических категориях. Конфликтность усиливала ориентация основной массы мигрантов на занятость в остро конкурентном мелком и среднем бизнесе, а также видимый успех некоторых из них. Часть российской элиты сознательно фрормировала из выходцев с Кавказа «образ врага».

Теперь «кавказцы» - это «гости», «наглые чужаки», не желающие уважать порядки и обычаи «хозяев». «Торгаши», навязывающие враждебную систему ценностей. Люди, связанные круговой порукой общинных отношений, несущие поэтому коллективную ответственность (Дятлов 2008). Фактор гражданства не играет заметной роли, общество пока привыкает к существованию «нового зарубежья» и не воспринимает его как настоящую заграницу. В огромной степени комплекс «кавказца» - это порождение «национального дискурса».

Однако к концу 1990-х годов «кавказофробия» отходит на задний план. Миграционная волна сократилась и потеряла прежний «залповый» характер. В результате быстрой адаптации мигрантов они перестают выделяться типом поведения и образом жизни. Все больше выясняется, что тревожили раньше, стимулировали страх и вражду не «кавказская этничность», не облик и не расовые характеристики («черные»), а модель поведения, образ и стиль жизни. Уходит негативный образ «торгаша».

Все это выявило слабые инструментальные возможности конструкта «национальности» и «национальных отношений». Власти, которые в 1990-е годы бросились проводить «национальную политику», создавая для этого соответствующие институции и разрабатывая нормативные документы, довольно быстро к этому охладели. Было закрыто соответствующее министерство, рутинизировались и потеряли прежнее значение взаимоотношения с национальнокультурными обществами.

Внезапное появление массы мигрантов из Китая в начале 1990-х годов стало для подавляющего большинства россиян абсолютной неожиданностью. Более того - огромным шоком. Массовое присутствие китайских мигрантов не 
сформировало пока обстановку повседневного привычного, рутинного человеческого контакта с ними, пусть даже такого конфликтного как с «кавказцами». Контакта хотя бы относительно индивидуализированного - через коллег, деловых партнеров, постоянных и лично знакомых торговцев, через совместную трудовую деятельность. Поэтому, возможно, пока нет особого стимула к тому, чтобы фрормировался индивидуализированный образ китайца.

Мелких торговцев, рабочих-строителей, вообще трудовых мигрантов из Китая, сразу стали называть «китайцами». «Китаец» в таком понимании - это и этнический китаец, и житель Китая, и гражданин КНР. Это конечно, не «иностранец» в советском понимании, но представитель, частица гигантской державы, с которой еще совсем недавно отношения находились на грани военного противостояния. Именно остро ощущаемое присутствие за спиной мигрантов огромной и набирающей силу страны практически сразу отодвинуло этническую сторону категории «китаец» и выделило, подчеркнуло сторону державную, проблему гражданства. В построениях рубежа XIX-XX вв. китаец выглядит куда менее этатизированным, растворенным не в государстве, а в группе, в «расе».

Почти вышел из употребления эпитет «желтый», принципиально важный для рубежа XIX-XX веков. Он сохранился в словосочетании «желтая опасность» - но скорее в качестве компонента устоявшегося термина. Вряд ли это результат политкорректности. Скорее - следствие ухода на периферию мощного, возможно, преобладавшего в конце XIX - начале XX века расового дискурса. Переход от «желтого» к «китайскому» кажется нам принципиальным отличием в самых фундаментальных характеристиках образа китайца двух рассматриваемых эпох.

В общественно-политический оборот, в масс-медиа, в обыденные представления и речь обычных людей вошло и быстро стало господствующим определение «китайский мигрант». Это показатель явного переключения внимания от сферы культурных характеристик к социально-экономической функции. Внутри этой формулы шло движение от «китайского» к «мигранту». «Китайскость» оставалась значимой в качестве маркера принадлежности к государству, а не культуре, этнической группе.

Следующая мощная миграционная волна была связана с Центральной Азией. Ее первопроходцами стали жители Таджикистана, таджики по этнической принадлежности. В качестве новичков они не могли рассчитывать на стартовые возможности выходцев с Кавказа, которые еще с советских времен накопили значительные материальные возможности, опыт, деловые и социальные связи. Они могли рассчитывать только на самые непривлекательные, грязные и низкооплачиваемые профессии и сферы занятости. Через несколько лет, отчасти опираясь на созданную ими миграционную инфраструктуру, пришли в движение жители соседнего Узбекистана, миграционный потенциал которого много выше, чем у Таджикистана.

Первопроходческая роль таджиков, их массовое, повседневное и постоянное присутствие в жизни принимающего общества, сформировало «образ таджика». Само это слово наполнилось новыми смыслами. Оно осталось привычным этнонимом и обозначением жителя и гражданина Таджикистана. Однако, его распространяют теперь на всех выходцев из Центральной Азии, приезжающих в Россию в поисках работы, преимущественно временной, сезонной. И причина этого не только в том, что мало кто в принимающем обществе отличает, скажем, таджика от узбека. «Таджик» стал массовой и привычной фригурой, частью обыденной жизни, повседневности. Появились устойчивые слово- 
сочетания «таджикский труд», «таджикская зарплата». «Работать как таджик». И даже - «работать таджиком».

Соответственно, фоомируется и образ, стереотип «таджика». Естественно, это выходец из Центральной Азии, совсем не обязательно собственно таджик. При численном преобладании узбеков, например, они в этом качестве в общественном мнении и сознании практически отсутствуют. Это не русский или, по распространенному определению, «русскоязычный». Подразумевается при этом - не европеец. Впрочем - и не среднеазиатский кореец или татарин. Здесь явственно подразумеваются расовые характеристики, хотя это не вербализируется, а часто не осознается. Это человек не просто приезжий, но временный, «перелетная птица». Это человек второго сорта, низкостатусный и бесправный, не претендующий на чье-либо место в социальной иерархии, готовый на любой труд, вообще на все ради заработка. Он даже не внизу социальной лестницы - он вне ее. «Таджик» перестает быть этничностью и даже гражданством. Он превращается в синоним «трудового мигранта». В этом можно увидеть тенденцию постепенного вытеснения ранее господствовавшего национального дискурса дискурсом социальным - миграционным. Мигранты заняли такое огромное место в жизни российского общества и оказались настолько уникальным френоменом, что возникла потребность в собственном, отдельном отношении и стереотипе.

Ответом на эту потребность стало вхождение в обыденную речь слова «гастарбайтер", которое прежде использовалось крайне редко и исключительно в специальной литературе. По словам С. Абашина, «незаметный переход от "мигранта» к "гастарбайтеру» переключает тему с вопросов географического перемещения на вопросы социальных взаимодействий на рынке труда» (Абашин 2012: 6). Родившееся в Германии, это слово отразило и сдвиг в понимании и восприятии обществом проблемы - в частности, радикальный переход от этнического принципа стереотипизации к мигрантскому.

Сквозь огромную массу самых разнообразных текстов последних лет проступают основные черты гастарбайтера. Во многом, это продолжение и развитие «таджика». Это пришлый, не местный человек, «мигрант», приехавший из-за границы, чтобы заработать денег и уехать. Его этничность, культура, страна происхождения, личные качества никого не интересуют. Его присутствие не очень желательно, оно раздражает, но приходится с ним мириться, ибо кому-то же надо трудиться на грязных и низкооплачиваемых работах. Он должен «знать свое место» - и место это находится вне социальной иерархии принимающего общества. Чем меньше его видно, тем лучше.

Этнические, расовые, гражданские характеристики и различия при таком взгляде элиминируются. Становится важной социально-экономическая функция - «трудовой мигрант». Эта группа наделяется общими социальными и психологическими характеристиками, формируется представление об общности образа и стиля жизни ее представителей. Подразумевается их особый правовой статус и параметры и критерии этого статуса не сводятся к гражданству. Как раз существующие в этой правовой сфере реальные различия (мигранты из визовых и невизовых стран, из стран, имеющих льготные мигрантские режимы и не имеющих таковых и т.д.) особой роли не играют. Иностранный гражданин, работающий в России на высокооплачиваемой и статусной позиции - это вовсе не гастарбайтер. Они выделены как объект специального правового регулирования именно в качестве трудовых мигрантов. И это заставляет вспомнить уже о сословной системе. 
Заключение. Таким образом, в позднеимперской и постсоветской России мы видим постоянные попытки понять феномен трансграничных миграций через систему этнических категорий. Попытки обычно не слишком успешные, заставляющие искать слова и образы в других проблемных плоскостях. Это принципиально важно, т.к. выбор слов - это выбор отношения и политики.

Россия дает уникальную возможность сравнить востребованость этнического дискурса для понимания и оценки трансграничной трудовой миграции в две исторические эпохи, разделенные еще одной - советской эпохой. Очень важно то, что, хотя в советскую эпоху изучаемый феномен почти исчез, полного идеологического и культурного разрыва для его понимания все-таки не произошло. Своеобразным «мостиком» стал как раз этнический дискурс. Говоря словами той (и предшествующей) эпохи - «национальный подход», «национальный вопрос».

Понять его описательную и оценивающую роль невозможно без одновременного анализа роли сопутствующих подходов - расового, сословного, нормативно-юридического (подданство и гражданство), социально-экономического («трудовые мигранты», «гастарбайтеры»).

Мы можем видеть, как в позднеимперскую эпоху набирающий силу и эвристические возможности «национальный подход» скрывается «в тени» расового или используется в качестве его дополнения. Как он соотносится с живым еще сословным дискурсом и языком. Как это может вступать в противоречие с развитыми и укоренными в сфрере государственного функционирования категориями права, особенно права международного.

Благодаря господству в советскую эпоху, «национальный» взгляд и язык, теперь уже как вполне органичные и принятые не только идеологией, но и массовым сознанием, стали естественным и господствующим инструментом описания и оценки массовых трансграничных трудовых миграций после социализма. Однако, хотя этим языком в качестве общепризнанного стали широко пользоваться и власти, и масс-медиа, и простые обыватели, и, осторожно сформулируем, заметная часть научного сообщества, довольно скоро выявились его ограниченные эвристические возможности. Иначе говоря, миграционная ситуация не вмещалась в «национальный» язык. Это могло даже не осознаваться и не подвергаться рефлексии, однако в массовый оборот плавно входят, а затем и начинают преобладать, слова из социально-экономического словаря - «мигранты», «трудовые мигранты», «гастарбайтеры».

Эта динамика не означала полной замены одной системы представлений и языка описания другой. Происходит скорее напластование, сосуществование и взаимодействие, когда меняется иерархия дискурсов, но не их замена. Даже расовый подход, казалось бы, полностью дискредитированный и вытесненный событиями XX века, оставил после себя заметный шлейфр слов и образов. На смену «желтым» позднеимперской эпохи пришли «черные» времен позднего социализма и постсоциалистического транзита. Однако при всей живучести, это теперь язык явно маргинальный, вытесненный из публичной сферы, потерявший эвристическую функцию. За словом «желтый» могло стоять вполне нейтральное отношение, констатация, с точки зрения автора, непреодолимых природных различий. «Черные» - это исключительно оскорбление.

Тем более это относится к этническому языку описания. У него сохраняются прочные позиции по совершенно очевидной объективной причине. Миграционные процессы имеют явную и мощную этнокультурную составляющую, игнорировать которую не эвристично с научной точки зрения и опасно с общественно-политической. Вопрос здесь в приоритетах и адекватном использова- 
нии языков описания. Понятно, что это во многом стихийный и слабо регулируемый процесс. Миграционная ситуация динамично развивается. Не менее динамично меняется российское общество и его отношение к проблеме присутствия мигрантов. Процесс осмысления и вербализации миграционного феномена в России далеко не завершен. Возможна как новая конфигурация уже известных и апробированных подходов, так и радикальные перемены в языке описания и оценки.

\section{Әдебиеттер тізімі/ Список литературы}

1. Абашин С.Н. Среднеазиатская миграция: практики, локальные сообщества, транснационализм // Этнографическое обозрение. - 2012. - №4.

2. Валетов Т.Я. Самоорганизованные сезонные бригады (шабашники) в СССР в 1960-1980-х гг.: экономические и социальные аспекты // Экономическая история. Обозрение. Выпуск 14 / Под ред. Л. И. Бородкина. - М.: Изд-во МГУ, 2008. - С.203-226.

3. Граве В.В. Китайцы, корейцы и японцы в Приамурье. Отчет Уполномоченного Министерства Иностранных Дел В.В. Граве // Труды командированной по Высочайшему повелению Амурской экспедиции. Вып.XІ. - СПб, 1912.

4. Дятлов В. «И тогда мама взяла обрез...» Самосуд и отношение к «чужакам» в общественном мнении российской провинции 1990-х годов // Вестник Евразии. - 2008. - №4(42). - С.142-176.

5. Дятлов В.И. Миграция китайцев и дискуссия о «желтой опасности» в дореволюционной России // Вестник Евразии. - 2000. - №1. - С.63-89.

6. Ларин А.Г. Китайские мигранты в России. История и современность. - М.: Восточная книга, 2009.

7. Л.Г. Желтый труд на Дальнем Востоке по данным 1914 года // Вопросы колонизации. - 1916. - №19. - С.140-171.

8. Левинсон А. «Кавказ» подо мною. Краткие заметки по формированию и практическому использованию «образа врага» в отношении «лиц кавказской национальности» // Образ врага. М.: ОГИ, 2005. - С.276-301.

9. Мацокин П.Г. Оценка данных производств в японских, китайских и европейских ремесленнопромышленных заведениях за 1910-1911 гг. // Вестник Азии. - 1911. - №10. - С.1-20.

10. Панов А. Желтый вопрос в Приамурье // Вопросы колонизации. - 1910. - №7. - С. 53-116.

11. Петров А.И. Корейская диаспора в России. 1897 - 1917 гг. - Владивосток: ДВО РАН, 2001.

12. Предварительные итоги бюджетного обследования рабочих и служащих Дальнего Востока в марте 1924 г. - Хабаровск, 1925.

13. Сорокина Т.Н. Проект иммиграционного закона для областей Дальнего Востока 1914 г. как исторический источник // Документ в контексте истории: материалы 11 Межд. науч. конф. - Омск, 2009. - С.197-204.

14. Унтербергер П.Ф. Приморская область 1856-1898 гг. - СПб., 1900.

15. Юрчак А. Это было навсегда, пока не кончилось. Последнее советское поколение. - М.: Новое литературное обозрение, 2016. - С. 311-314.

16. Merlin A., Radvani J. Russes et Caucasiens a` la fin du XX Siecle. Identites et territories // Revue d`etudes comparatives Est-Ouest. - 2003. - Vol.34. - №4. - P.77-94

17. Siegelbaum L.H., Moch L.P. Broad Is My Native Land: Repertoires and Regimes of Migration in Russia`s Twentieth Century. Cornell Univ. press, 2014. - P.16-65.

\section{Reference}

Abashin 2012 - Abashin, SN 2012, Sredneaziatskaya migraciya: praktiki, lokal'nye soobshchestva, transnaciona-lizm, Ethnographic review, №4. (Abashin, SN 2012, Central Asian migration: practices, local communities, transnationalism, EHtnograficheskoe obozrenie, №4). (in Rus).

Grave 1912 - Grave, VV 1912, Kitajcy, korejcy i yaponcy v Priamur'e. Otchet Upolnomochennogo Ministerstva Inostrannyh Del V.V. Grave, Trudy komandirovannoj po Vysochajshemu poveleniyu Amurskoj ehkspedicii. Vyp.XI, Saint Petersburg. (Grave, VV 1912, Chinese, Koreans and Japanese in the Amur region. The Report Of The Commissioner Of The Ministry Of Foreign Affairs.V. Grave, Proceedings of the Amur expedition sent by the Highest command. Issue XI, Saint Petersburg). (in Rus).

Dyatlov 2000 - Dyatlov, VI 2000, Migraciya kitajcev i diskussiya o «zheltoj opasnosti» v dorevolyucionnoj Rossii, Vestnik Evrazii, №1, P.63-89. (Dyatlov, VI 2000, Chinese Migration and discussion about the «yellow danger» in pre-revolutionary Russia, Bulletin of Eurasia, №1, P.63-89). (in Rus). 
Dyatlov 2008 - Dyatlov, V 2008, «I togda mama vzyala obrez...» Samosud i otnoshenie k «chuzhakam» v obshchestven-nom mnenii rossijskoj provincii 1990-h godov, Vestnik Evrazii, №4(42), P.142-176. (Dyatlov, V 2008, «And then mom took the sawed-off...» Lynching and attitude to "outsiders» in the public opinion of the Russian province of the 1990s, Bulletin of Eurasia, №4(42), P.142-176). (in Rus).

Larin 2009 - Larin, AG 2009, Kitajskie migranty v Rossii. Istoriya i sovremennost', Vostochnaya kniga, Moscow. (Larin, AG 2009, Chinese migrants in Russia. History and modernity, Vostochnaya kniga, Moscow). (in Rus).

L.G. 1916 - LG 1916, ZHeltyj trud na Dal'nem Vostoke po dannym 1914 goda, Voprosy kolonizacii, №19, P.140-171. (LG 1916, Yellow labor in the far East according to 1914, Questions of colonization, №19, P.140-171). (in Rus).

Levinson 2005 - Levinson, A 2005, «Kavkaz» podo mnoyu. Kratkie zametki po formirovaniyu i prakticheskomu is-pol'zovaniyu «obraza vraga» v otnoshenii «lic kavkazskoj nacional'nosti», Obraz vraga, OGI, Moscow, P.276-301. (Levinson, A 2005, «Caucasus» under me. Brief notes on the formation and practical use of the «image of the enemy» in relation to «persons of Caucasian nationality", Image of the enemy, OGI, Moscow, P.276-301). (in Rus).

Macokin 1911 - Macokin, PG 1911, Evaluation of these productions in Japanese, Chinese and European handicraft and industrial institutions for 1910-1911, Vestnik Azii, №10, P.1-20. (Macokin, PG 1911, Ocenka dannyh proizvodstv v yaponskih, kitajskih i evropejskih remeslenno-promyshlennyh zavedeniyah za 1910-1911 gg., Bulletin of Asia, №10, P.1-20). (in Rus).

Merlin, Radvani 2003 - Merlin, A, Radvani, J 2003, Russes et Caucasiens à la fin du XX Siecle. Identites et territories, Revue d'etudes comparatives Est-Ouest, Vol.34, №4, P.77-94. (Merlin, A, Radvani, J 2003, Russian and Caucasiens in` La fin du XX century. Identities et territories, Revue d'etudes comparatives Est-Ouest, Vol.34, №4, P.77-94). (in Fra).

Panov 1910 - Panov, A 1910, ZHeltyj vopros v Priamur'e, Voprosy kolonizacii, №7, P.53-116. (Panov, A 1910, Yellow question in the Amur region, Questions of colonization, №7, P.53-116). (in Rus).

Petrov 2001 - Petrov, Al 2001, Korejskaya diaspora v Rossii. 1897-1917 gg, DVO RAN, Vladivostok. (Petrov, Al 2001, The Korean Diaspora in Russia. 1897-1917, DVO RAN, Vladivostok). (in Rus).

Predvaritel'nye itogi byudzhetnogo 1925 - Predvaritel'nye itogi byudzhetnogo obsledovaniya rabochih $i$ sluzhashchih Dal'nego Vostoka v marte 1924 g. 1925, Habarovsk. (Preliminary results of the budget survey of workers and employees of the Far East in March 1924. 1925, Khabarovsk). (in Rus).

Siegelbaum, Moch 2014 - Siegelbaum, LH, Moch, LP 2014, Broad Is My Native Land: Repertoires and Regimes of Migration in Russia`s Twentieth Century. Cornell Univ. press, 2014. - P.16-65. (in Eng).

Sorokina 2009 - Sorokina, TN 2009, Proekt immigracionnogo zakona dlya oblastej Dal'nego Vostoka 1914 g. kak istoricheskij istochnik, Dokument $v$ kontekste istorii: materialy 11 Mezhd. nauch. Konf,. Omsk, P.197-204. (Sorokina, TN 2009, The draft immigration law for the regions of the Far East in 1914 as a historical source, Document in the context of history: materials 11 Inter. scientific. Conf. Omsk, P.197-204). (in Rus).

Unterberger 1900 - Unterberger, PF 1990, Primorskaya oblast' 1856-1898 gg, Saint Petrsburg. (Unterberger, PF 1990, Primorskaya oblast 1856-1898, Saint Petrsburg). (in Rus).

Valetov 2008 - Valetov, TYa 2008, Samoorganizovannye sezonnye brigady (shabashniki) v SSSR v 1960-1980-h gg.: ehkonomicheskie i social'nye aspekty, EHkonomicheskaya istoriya. Obozrenie, Vypusk 14, Ed. LI Borodkina, Izd-vo MGU, Moscow, P.203-226. (Valetov, TYa 2008, Selforganized seasonal teams (shabashniki) in the USSR in 1960-1980-ies: economic and social aspects, Economic history. Review, Vypusk 14, Ed. LI Borodkina, Izd-vo MGU, Moscow, P.203226). (in Rus).

YUrchak 2016 - YUrchak, A 2016, EHto bylo navsegda, poka ne konchilos'. Poslednee sovetskoe pokolenie, Novoe literaturnoe obozrenie, Moscow, P.311-314. (YUrchak, A 2016, it was forever until it was over. The last Soviet generation, Novoe literaturnoe obozrenie, Moscow, P.311-314). (in Rus). 